\title{
Investigation of the Factors Associated with Mortality in Catheter-Related Bloodstream Infections: Five-Year Observation
}

\author{
Kateter İlişkili Kan Dolaşımı Enfeksiyonlarında Mortalite ile İlişkili Faktörlerin Araştırılması: Beş \\ Y1llik Gözlem
}

\author{
Nevin INCE ${ }^{1}$ \\ (1) 0000-0002-0129-4536 \\ Dilek YEKENKURUL ${ }^{1}$ \\ (D) 0000-00002-4456-7485 \\ Emel ÇALIŞKAN ${ }^{2}$ \\ (D) 0000-0002-9451-7865 \\ Ali Rıza GÜRBÜZ ${ }^{1}$ \\ (D) 0000-0002-0106-9582 \\ Selvi YENER ${ }^{3}$ \\ (D) 0000-0001-5022-940X
}

\begin{abstract}
Aim: Intravenous catheter use can cause various infections ranging from infection at the site of catheter entry to bacteremia and colonization. The purpose of this study was to identify the causative micro-organisms, and effects on morbidity-mortality of catheter-related bloodstream infections developing over the last five years.

Material and Methods: Data for 194 patients who underwent central intravenous catheter insertion in our hospital's intensive care unit and other departments between November 2014 and August 2019 were analyzed retrospectively. Blood samples taken from the catheter or the catheter tip, and blood samples collected simultaneously from the peripheral vein were included in the study, and culture results were recorded. Patients' demographic data and the effects of the factors identified on morbidity and mortality were subjected to statistical analysis.

Results: Ninety-two (47.4\%) of the 194 patients included in the study were female and 102 $(52.6 \%)$ were male, and mortality rate was $62.4 \%(n=121)$. The frequency of underlying medical conditions such as asthma, congestive heart failure, and cerebrovascular event, and

\section{Candida species.} ${ }^{1}$ Duzce University Faculty of Medicine receiving treatments such as immunosuppression, transfusion, tracheostomy, nasogastric tube, Department of Infectious Diseases and and mechanical ventilation were higher in mortal cases than non-mortal cases. A total of two Clinical Microbiology, Duzce, Turkey hundred and forty microorganisms were detected in 194 patients, 121 (50.4\%) of which were ${ }^{2}$ Duzce University Faculty of Medicine Gram negative bacteria, while 68 (28.3\%) were Gram positive bacteria, and 51 (21.3\%) were Department of Medical Microbiology, Duzce, Turkey

${ }^{3}$ Duzce University Faculty of Medicine Infection Control Committee, Duzce, Turkey

\section{Corresponding Author Sorumlu Yazar \\ Nevin İNCE \\ drnevince@gmail.com}

Received / Geliş Tarihi : 16.06 .2020 Accepted / Kabul Tarihi : 15.09.2020 Available Online /

Çevrimiçi Yayın Tarihi : 25.12.2020
Conclusion: As a result, it was observed that the advanced age, underlying diseases and presence of resistant microorganisms were higher in mortal cases.

Keywords: Catheter-related bloodstream infections; mortality; advanced age.

\section{ÖZ}

Amaç: İntravenöz kateter kullanımı hastalarda kateter girişindeki enfeksiyondan bakteriyemi ve kolonizasyona kadar çeşitli enfeksiyonlara neden olabilir. Bu çalışmanın amacı, son beş yılda gelişen kateter ilişkili kan dolaşımı enfeksiyonlarının etken mikroorganizmalarını tanımlamak ve morbidite-mortalite üzerine etkisini ortaya koymaktır.

Gereç ve Yöntemler: Kasım 2014 ve Ağustos 2019 tarihleri arasında hastanemizin yoğun bakım ünitesinde ve hastanemizin diğer bölümlerinde santral intravenöz kateter yerleştirilen 194 hastanın verileri geriye dönük olarak incelendi. Kateterden veya kateter ucundan alınan kan örnekleri ve periferik venden aynı anda toplanan kan örnekleri çalışmaya dahil edildi ve alınan kan örneklerinin kültür sonuçları kaydedildi. Hastaların demografik verileri ile saptanan faktörlerin morbidite ve mortalite üzerine olan etkileri istatistiksel olarak değerlendirildi.

Bulgular: Çalışmaya dahil edilen 194 hastanın 92'si $(\% 47,4)$ kadın, 102'si $(\% 52,6)$ erkek cinsiyette idi ve mortalite oranı \%62,4 $(n=121)$ idi. Astım, konjestif kalp yetmezliği ve serebrovasküler olay gibi altta yatan tıbbi durumların sıklı̆̆ ve immünosupresyon, transfüzyon, trakeostomi, nazogastrik tüp ve mekanik ventilatör uygulanması gibi tedavilerin sıklığı mortal olgularda mortal olmayan olgulardan daha fazla idi. Yüz doksan dört hastada toplam 240 adet mikroorganizma üremesi saptanmış olup bunların $121(\% 50,4)$ 'i Gram negatif bakteri, 68 (\%28,3)'i Gram pozitif bakteri ve $51(\% 21,3)$ 'i Candida spp idi.

Sonuç: Sonuç olarak ileri yaş, altta yatan hastalıklar ve dirençli mikroorganizma varlığının mortal olgularda daha fazla olduğu görülmüştür.

Anahtar kelimeler: Kateter ilişkili kan dolaşımı enfeksiyonu; mortalite; ileri yaş. 


\section{INTRODUCTION}

In addition to raising costs, healthcare-related infections extend hospital stays and exacerbate poor prognosis and mortality (1). Catheter-related bloodstream infection (CRBSI) is the third most common nosocomial infection after ventilator-associated pneumonia and catheter-related urinary tract infection. The incidence of CRBSI decreases when protective bundles and infection control measures are applied, although the rate of infection may vary depending on the site of the catheter, the size of the hospital, and intensive care conditions (2). More than two billion intravenous devices are applied annually worldwide (3). In the USA, 250,000 patients are diagnosed with CRBSI every year, an average of 80,000 of whom are being treated in intensive care units (4). In addition to prolonging hospital stays and causing higher costs, CRBSI is one of the deadliest infections, with a mortality rate of $12-25 \%(5-7)$. Central venous catheters (CVCs) allow micro-organisms to enter and colonize the body. These pathogenic microorganisms adhere to the surface of the catheter within the first 24 hours and form a biofilm layer that prepares the ground for infection by competing with the host cells $(8,9)$. This allows micro-organisms to protect themselves against both antimicrobials and the immune system, and catheters need to be removed in most cases (10). Micro-organisms frequently implicated in CVC infections include Acinetobacter baumannii, Staphylococcus epidermidis, Enterococcus faecium, and Candida albicans $(9,11)$.

The purpose of this study was identify the causative microorganisms, and the effects on morbidity-mortality of CRBSI developing in our hospital over the last five years.

\section{MATERIAL AND METHODS}

Data for 194 patients in whom CVCs were inserted in our hospital's intensive care unit and other departments between November 2014 and August 2019 were analyzed retrospectively. Development of CRBSI was identified from data from the laboratory and clinic-based active surveillance system based on US Centers for Disease Control and Prevention criteria (2). The culture results of blood samples taken from the catheter or the catheter tip and blood samples taken from the peripheral vein were examined. Catheter samples were seeded using the semiquantitative culture method. Culture plates were incubated at $37^{\circ} \mathrm{C}$ for 48 hours. Cultures from peripheral venous and catheter blood were incubated in a BACTEC 9120 (Becton Dickinson, USA) automated blood culture device. Conventional methods and/or the VITEK 2 automated system (bioMérieux, France) were used to identify the growing bacteria. Antibiotic susceptibility tests were performed according to "Clinical and Laboratory Standards Institute (CLSI)" standards (12) before 2016, and in line with "European Committee on Antimicrobial Susceptibility Testing (EUCAST)" standards (13) after 2016. Additional diseases such as asthma, hypertension, diabetes, and risk factors including mechanical ventilation, transfusion and immunosuppression were investigated. Infection Control Committee surveillance records were used to collect all data.

This study was approved by the Clinical Research Ethics Committee of Düzce University Medical Faculty on 15.06.2020 with decision number 130 and was conducted according to the Helsinki Declaration principles.

\section{Statistical Analysis}

SPSS v.22 software was used for data analysis. The data were expressed as numbers and percentages. Relationships between categorical variables were examined by Pearson chi-square, Fisher's exact and Fisher-Freeman-Halton tests. A $p$ value of $<0.05$ was considered significant.

\section{RESULTS}

One hundred ninety-four patients, $92(47.4 \%)$ female and $102(52.6 \%)$ male, were included in the study. One hundred twenty-one $(62.4 \%)$ patients with CRBSI died. One hundred eleven $(57.2 \%)$ patients were aged 65 and over, and $83(42.8 \%)$ were under 65 . The mortality rate was significantly higher in patients aged 65 and over ( $\mathrm{p}<0.001)$. Twenty-eight $(14.4 \%)$ patients were treated on the wards and $166(85.6 \%)$ in intensive care units. While the frequency of patients hospitalized in the internal intensive care unit (IICU) was higher in mortal cases than the non-mortal cases, the frequency of patients hospitalized in internal ward and pediatric intensive care unit (PICU) were lower in mortal cases than the nonmortal cases $(p<0.001)$. Analysis of catheter sites revealed similar relationships between jugular, femoral, umbilical, or subclavian catheter applications and mortality rates $(\mathrm{p}=0.903)$. Analysis of comorbidities and risk factors revealed that the presence of asthma, congestive heart failure (CHF) and cerebrovascular event (CVE) were associated with mortality rates $(\mathrm{p}=0.015, \mathrm{p}=0.033$ and $\mathrm{p}=0.039$, respectively). While the frequency of immunosuppression $(\mathrm{p}=0.048)$, transfusion $(\mathrm{p}=0.046)$, nasogastric tube $(\mathrm{p}<0.001)$, and mechanical ventilation $(\mathrm{p}=0.005)$ in mortal cases was higher than the non-mortal cases, the frequency of enteral nutrition $(\mathrm{p}=0.011)$ was lower in mortal cases than the non-mortal cases. While infection with single or multiple factors caused no statistically significant difference in mortality rates $(\mathrm{p}=0.167)$, the mortality rate in resistant microorganism growth was higher than that in susceptible agent growth $(\mathrm{p}=0.004)$. All these data are summarized in Table 1.

A total of 240 microorganisms were detected in 194 patients in the study. Infection occurred in $149(76.8 \%)$ patients with a single agent and in $45(23.2 \%)$ of patients with multiple agents. One hundred twenty-one $(50.4 \%)$ of the 240 micro-organisms were identified as Gram negative bacteria, $68(28.3 \%)$ as Gram positive bacteria, and 51 $(21.3 \%)$ as Candida species. The distribution of agents is shown in Table 2. Extended spectrum beta-lactamase (ESBL) positivity rates were $62 \%$ in Klebsiella pneumoniae strains and $60 \%$ in Escherichiae coli strains, while the carbapenem resistance rate was $34 \%$ in $K$. pneumoniae strains. In addition, two carbapenem-resistant Enterobacter aerogenes and one colistin-resistant Acetinobacter baumannii strain were detected. Vancomycin resistance was detected in three out of $17 \mathrm{E}$. faecium strains among the enterococci.

\section{DISCUSSION}

The 2019 National Vascular Access Management Guide lists risk factors as prolonged hospitalization before catheter insertion, colonization of the inserted area and lumen, long-term catheter insertion, presence of internal jugular and femoral catheter in adults, prematurity, neutropenia, lack of intensive care nurses, catheter care 
errors, total parenteral nutrition (TPN) support, and blood transfusion in children $(10,11)$. The site of CVC is important for the risk of developing complications such as thrombophlebitis due to the local skin flora causing the infection (14-16). One randomized controlled study comparing the femoral and subclavian catheter insertion sites reported a higher colonization rate in the femoral region (17). Another study compared the subclavian and internal jugular veins and reported that catheters inserted into the internal jugular vein were exposed to higher colonization (18). A study conducted in 2017 reported infection rates of $36 \%$ for the internal jugular vein, $35.5 \%$ for the femoral vein, and $30 \%$ for the subclavian vein (19).

Table 1. Distribution of the features of patients and agents in mortal and non-mortal cases, n (\%)

\begin{tabular}{|c|c|c|c|}
\hline & $\begin{array}{l}\text { Mortal } \\
(n=121)\end{array}$ & $\begin{array}{c}\begin{array}{c}\text { Non-mortal } \\
(n=73)\end{array} \\
\end{array}$ & $\mathbf{p}$ \\
\hline \multicolumn{4}{|l|}{ Gender } \\
\hline Female & $62(51.2)$ & $30(41.1)$ & \multirow{2}{*}{0.170} \\
\hline Male & $59(48.8)$ & $43(58.9)$ & \\
\hline \multicolumn{4}{|l|}{ Age } \\
\hline$\geq 65$ & $82(67.8)$ & $29(39.7)$ & \multirow{2}{*}{$<0.001$} \\
\hline$<65$ & 39 (32.2) & $44(60.3)$ & \\
\hline \multicolumn{4}{|l|}{ Clinics } \\
\hline SICU & $62(51.2)^{\mathrm{a}}$ & $35(47.9)^{\mathrm{a}}$ & \multirow{5}{*}{$<0.001$} \\
\hline IICU & $48(39.7)^{\mathrm{a}}$ & $11(15.1)^{\mathrm{b}}$ & \\
\hline Internal ward & $9(7.4)^{\mathrm{a}}$ & $17(23.3)^{\mathrm{b}}$ & \\
\hline PICU & $1(0.8)^{\mathrm{a}}$ & $9(12.3)^{b}$ & \\
\hline Surgical ward & $1(0.8)^{\mathrm{a}}$ & $1(1.4)^{\mathrm{a}}$ & \\
\hline \multicolumn{4}{|l|}{ Catheter type } \\
\hline Femoral & $72(59.5)$ & $42(57.5)$ & \multirow{4}{*}{0.903} \\
\hline Juguler & $35(28.9)$ & $21(28.8)$ & \\
\hline Subclavian & $13(10.7)$ & $10(13.7)$ & \\
\hline Umbilical & $1(0.8)$ & $0(0.0)$ & \\
\hline \multicolumn{4}{|l|}{ Risk factors* } \\
\hline Asthma & $9(7.4)$ & $0(0.0)$ & 0.015 \\
\hline $\mathrm{CHF}$ & $26(21.5)$ & $7(9.6)$ & $\mathbf{0 . 0 3 3}$ \\
\hline CVE & $16(13.2)$ & $3(4.1)$ & 0.039 \\
\hline Hypertension & $60(49.6)$ & $36(49.3)$ & 0.971 \\
\hline Diabetes & $39(32.2)$ & $17(23.3)$ & 0.183 \\
\hline CAD & $22(18.2)$ & $8(11.0)$ & 0.178 \\
\hline $\mathrm{CRF}$ & $19(15.7)$ & $14(19.2)$ & 0.533 \\
\hline COPD & $13(10.7)$ & $3(4.1)$ & 0.104 \\
\hline Enteral feeding & $109(90.1)$ & $56(76.7)$ & 0.011 \\
\hline TPN & $53(43.8)$ & $29(39.7)$ & 0.578 \\
\hline Immunosuppression & $52(43.0)$ & $21(28.8)$ & 0.048 \\
\hline Transfusion & $91(75.2)$ & 45 (61.6) & 0.046 \\
\hline Nasogastric tube & $108(89.3)$ & $46(63.0)$ & $<0.001$ \\
\hline Mechanical ventilation & $93(76.9)$ & $42(57.5)$ & 0.005 \\
\hline Hemodialysis & $43(35.5)$ & $21(28.8)$ & 0.331 \\
\hline \multicolumn{4}{|l|}{ Agent features } \\
\hline Single agent & $89(73.6)$ & $60(82.2)$ & \multirow{2}{*}{0.167} \\
\hline Multiple agent & $32(26.4)$ & $13(17.8)$ & \\
\hline \multicolumn{4}{|l|}{ Resistancy state } \\
\hline Group of resistant agent & $95(78.5)$ & $43(58.9)$ & \multirow{2}{*}{0.004} \\
\hline Group of sensitive agent & $26(21.5)$ & $30(41.1)$ & \\
\hline
\end{tabular}

SICU: Surgical intensive care unit, IICU: Internal intensive care unit, PICU: Pediatric intensive care unit, *: more than one factors in a patient, CHF: Congestive heart failure, CVE: Cerebrovascular event, CAD: Coronary artery disease, CRF: Chronic renal failure, COPD: Chronic obstructive pulmonary disease, TPN: Total parenteral nutrition, Group of resistant agent: Carbapenem resistant Gram negative bacteria, methicillin resistant staphylococcus, vancomycin resistant enterococcus and Candida spp., Group of sensitive agent: Vancomycin sensitive enterococcus, methicillin sensitive staphylococcus, carbapenem sensitive Gram negative bacteria and others
In the present study, rates of use were $58.5 \%$ in the femoral vein, $29 \%$ in the jugular vein, $12 \%$ in the subclavian vein, and $0.5 \%$ in the umbilical vein. Although the highest rate of use was observed in the femoral vein, analysis of mortality rates revealed identical values for the femoral catheter and jugular catheter, at $63 \%$, and a rate of $57 \%$ for the subclavian catheter. Although mortality rates for the subclavian catheter were relatively low, no significant difference in mortality rates was detected among the groups.

Age and the presence of risk factors such as immunosuppression and malignancy are important factors in the diagnosis of CRBSI (20). In a study by Hajjej et al. (21), the presence of diabetes mellitus or presence of sepsis at the time of catheter insertion, prolonged catheterization, and the use of antibiotics before insertion, even in a single dose, were identified as independent risk factors for the development of infection, with a reported mortality rate of $21.8 \%$. In Wittekamp et al. (22), the incidence of infection was high in central venous and arterial catheters, but even higher in arterial catheters. In a study from Turkey, advanced age, being treated in intensive care, use of antibiotics during catheterization, and prolonged catheterization were associated with the development of infection (14). In the present study, $57.2 \%$ of patients were over $65,85.6 \%$ were being treated in the intensive care unit, and $37.6 \%$ were immunosuppressive. When the departments in which patients were hospitalized were compared, mortality rates were higher in the IICU. We attributed this to patients receiving treatment in IICU being hospitalized for longer periods due to advanced age and

Table 2. Distribution of causative microorganism species

\begin{tabular}{|c|c|}
\hline Microorganism $(n=240)$ & n $(\%)$ \\
\hline Gram negative bacteria species & $121(50.4)$ \\
\hline Acinetobacter baumanni & $44(18.3)$ \\
\hline Klebsiella pneumonia & $29(12.1)$ \\
\hline Pseudomonas aeruginosa & $18(7.5)$ \\
\hline Escherichiae coli & $5(2.1)$ \\
\hline Serratia marcescens & $5(2.1)$ \\
\hline Enterobacter cloacae & $5(2.1)$ \\
\hline Enterobacter aerogenes & $4(1.7)$ \\
\hline Klebsiella oxytoca & $3(1.3)$ \\
\hline Pseudomonas putida & $2(0.8)$ \\
\hline Stenotrophomonas maltophilia & $2(0.8)$ \\
\hline Burkholderia cepaciae & $2(0.8)$ \\
\hline Morganella morganii & $1(0.4)$ \\
\hline Pantoae spp & $1(0.4)$ \\
\hline Gram positive bacteria species & $68(28.3)$ \\
\hline MRCNS & $31(12.9)$ \\
\hline Enterococcus faecium & $17(7.1)$ \\
\hline Enterococcus faecalis & $8(3.3)$ \\
\hline MRSA & $7(2.9)$ \\
\hline MSSA & $4(1.7)$ \\
\hline Corynebacterium spp. & $1(0.4)$ \\
\hline Fungal types & $51(21.3)$ \\
\hline Candida albicans & $26(10.8)$ \\
\hline Candida tropicalis & $10(4.2)$ \\
\hline Candida parapsilosis & $9(3.8)$ \\
\hline Candida glabrata & $3(1.3)$ \\
\hline Candida famata & $1(0.4)$ \\
\hline Candida lipolytica & $1(0.4)$ \\
\hline Candida guilliermondi & $1(0.4)$ \\
\hline
\end{tabular}
resistant Staphylococcus aureus, MSSA: Methicillin-sensitive Staphylococcus aureu 
comorbid disease, and to infections that developed with more resistant agents.

The present study also examined the effects of comorbid conditions, enteral nutrition, TPN, and mechanical ventilation on mortality rates. Asthma, CHF, CVE, and other risk factors such as transfusion, immunosuppression, tracheostomy, nasogastric tube, mechanical ventilation, and pulmonary artery catheter (PAC) were associated with mortality. While enteral nutrition is associated with mortality, it has been reported that TPN is not (10). This may be due to enteral nutrition, tracheostomy, nasogastric tube, PAC and mechanical ventilation being the most frequently applied interventions or treatments, especially in long-term hospitalizations and intensive care patients, and to the majority of our patients being treated in the ICU. Pichitchaipitak et al. (23) reported that long-term TPN use increased the rate of CRBSI.

While Gram-negative bacilli or S. aureus may be an agent in catheters inserted for a short period, Coagulase-negative staphylococci are generally factors in extended catheter insertion $(10,24)$. In their study of hematology, oncology, and intensive care patients, $78 \%$ of whom were immunosuppressive, Demirel et al. (25) observed that half of the factors consisted of Gram negative bacteria (50\%) and that Gram positive bacteria consisted of only $24.5 \%$. The rate of Candida species was $23.9 \%$. In a study involving hemodialysis patients, catheter infection factors were reported to be $60 \%$ Gram positive bacteria, $38 \%$ Gram negative bacteria, and $2 \%$ Candida spp. The authors of that study reported that only $20 \%$ of these patients had temporary catheters, the remaining $80 \%$ having permanent catheters, and that the incidence of infection in the temporary catheter group was higher than that in the permanent catheter group (26). All patients in the present study had temporary catheters, and the fact that information of the numbers of days with catheters could not be provided is a limitation of our study.

The relationship between susceptibility and mortality has also been investigated in recent research. In one study conducted in the hemodialysis unit, the reported carbapenem susceptibility of Gram-negative bacteria was $87.5 \%$, with an overall mortality rate of $10 \%$ (26). Analysis of the effects of micro-organisms on mortality in the present study revealed no significant difference between infections with single or multiple factors in terms of mortality rates. At least one resistant agent or Candida spp. was detected in the cultures of 95 patients who died (78.5\%). When our patients were divided into two groups based on the resistance status of microorganisms, the mortality rate was significantly higher in the group with resistant agents compared to the other group.

\section{CONCLUSION}

In conclusion, central catheter insertion is an invasive procedure and may result in morbidity and mortality by preparing the ground for infection. The purpose of this study was to contribute to the literature for Turkey by evaluating our own hospital's catheter infection data in the preceding five years. Advanced age and hospitalization in the IICU were more common in the mortal cases than the non-mortal cases. In addition, the frequency of resistant microorganisms in CRBSI was higher in mortal cases than non-mortal cases.
Ethics Committee Approval: The study was approved by the Ethics Committee of Düzce University Faculty of Medicine (15.06.2020, 130).

Conflict of Interest: None declared by the authors.

Financial Disclosure: None declared by the authors.

Acknowledgements: None declared by the authors.

\section{REFERENCES}

1. Editorial. Health care-associated infections in the USA. Lancet. 2015;385(9965):304.

2. O'Grady NP, Alexander M, Burns LA, Dellinger EP, Garland J, Heard SO, et al. Guidelines for the prevention of intravascular catheter-related infections, 2011. Atlanta, GA: Centers for Disease Control and Prevention; 2011.

3. Rickard C, Ullman A, Kleidon T, Marsh N. Ten tips for dressing and securement of IV device wounds. Aust Nursi Midwifery J. 2017;24(10):32-4.

4. O'Grady NP, Alexander M, Burns LA, Dellinger EP, Garland J, Heard SO, et al. Guidelines for the prevention of intravascular catheter-related infections. Clin Infect Dis. 2011;52(9):e162-93.

5. Wishnewski N, Kampf G, Gastmeier P, Schlingmann J, Daschner F, Schumacher N, et al. Prevalence of primary bloodstream infection in representative German hospitals and their association with central and peripheral vascular catheters. Zentralbl Bakteriol. 1998;287(1-2):93-103.

6. McHugh SM, Corrigan MA, Dimitrov BD, MorrisDownes M, Fitzpatric KF, Cowman S, et al. Role of patient awareness in prevention of peripheral vascular catheter-related bloodstream infection. Infect Control Hosp Epidemiol. 2011;32(1):95-6.

7. Srinivasan A, Wise M, Bell M, Cardo D, Edwards J, Fridkin S, et al. Vital signs: central line-associated blood stream infections--United States, 2001, 2008, and 2009. MMWR Morb Mortal Wkly Rep. 2011;60(8):243-8.

8. Del Pozo JL. Biofilm-related disease. Expert Rev Anti Infect Ther. 2018;16(1):51-65.

9. Timsit JF, Rupp M, Bouza E, Chopra V, Kärpänen T, Laupland K, et al. A state of the art review on optimal practices to prevent, recognize, and manage complications associated with intravascular devices in the critically ill. Intensive Care Med. 2018;44(6):742-59.

10. Ulusal Damar Erişimi Yönetimi Rehberi 2019. Hastane İnfeksiyonlar1 Dergisi. 2019;23(Ek 1):1-54.

11. Aktaş E, Sarı EN, Seremet Keskin A, Pişkin N, Külah C, Cömert F. Causative agents of intravenous catheterrelated infections and their antibiotic susceptibilities. Mikrobiyol Bul. 2011;45(1):86-92.

12. Clinical and Laboratory Standards Institute. Performance standards for antimicrobial susceptibility testing; twenty-fourth informational supplement. CLSI document M100-S24. Wayne, PA: CLSI; 2014.

13. eucast.org [Internet]. European Committee on Antimicrobial Susceptibility Testing. Breakpoint tables for interpretation of MICs and zone diameters. Version 6.0, valid from 2016-01-01. [Cited: 2020 April 30]. Available from: https://www.eucast.org/fileadmin 
/src/media/PDFs/EUCAST_files/Breakpoint_tables/v _6.0_Breakpoint_table.pdf.

14. Bekçibaşi M, Dayan S, Aslan E, Kortak MZ, Hoşoğlu S. Risk factors for central venous catheter-related bloodstream infections. Infez Med. 2019;27(3):258-65.

15. Bayazıt N, Erdinç Ş, Dizbay M, Yılmaz GR. Hastane infeksiyonları CDC yeni tanı kriterleri canlı konferans serisi. Hastane İnfeksiyonları Dergisi. 2013;3:270-75.

16. Loveday HP, Wilson JA, Pratt RJ, Golsorkhia M, Tinglea A, Bak A, et al. epic3: national evidence-based guidelines for preventing healthcare-associated infections in NHS hospitals in England. J Hosp Infect. 2014;86(Suppl 1):S1-70.

17. Merrer J, De Jonghe B, Golliot F, Lefrant JY, Raffy B, Barre E, et al. Complications of femoral and subclavian venous catheterization in critically ill patients: a randomized controlled trial. JAMA. 2001;286(6):700-7.

18. Parienti JJ, Mongardon N, Mégarbane B, Mira JP, Kalfon P, Gros A, et al. Intravascular complications of central venous catheterization by insertion site. $\mathrm{N}$ Engl J Med. 2015;373(13):1220-9.

19. Zhang M, Xu Y, Jiang Z, Qian J, Zhang Z, Sun N, et al. Study on risk factor of central venous catheter infection in ICU: 1160 patients report. Zhonghua Wei Zhong Bing Ji Jiu Yi Xue. 2017;29(12):1082-6.

20. Gürsoy B, Gelecek S, Yorganc1 K. Santral venöz kateter infeksiyonları. Yoğun Bakım Dergisi. 2006;6(4):196-203.
21. Hajjej Z, Nasri M, Sellami W, Gharsallah H, Labben I, Ferjani M. Incidence, risk factors and microbiology of central vascular catheter-related bloodstream infection in an intensive care unit. J Infect Chemother. 2014;20(3):163-8.

22. Wittekamp BH, Chalabi M, van Mook WN, Winkens B, Verbon A, Bergmans DC. Catheter-related bloodstream infections: a prospective observational study of central venous and arterial catheters. Scand J Infect Dis. 2013;45(10):738-45.

23. Pichitchaipitak O, Ckumdee S, Apivanich S, Chotiprasitsakul D, Shantavasinkul PC. Predictive factors of catheter-related bloodstream infection in patients receiving home parenteral nutrition. Nutrition. 2018;46:1-6.

24. Almirante B, Limón E, Freixas N, Guidol F, VINCat program. Laboratory-based surveillance of hospitalacquired catheter-related bloodstream infections in Catalonia. Results of the VINCat program (2007-2010). Enferm Infecc Microbiol Clin. 2012;30(Suppl 3):13-9.

25. Demirel A, Efe İris N, Çevik E, Koçulu S, Baygül A, Taşdelen Fışgın N. Catheter-related bloodstream infections: A multicentric five-year analysis. Klimik Derg. 2019;32(2):117-22.

26. Shah S, Singhal T, Naik R, Thakkar P. Incidence and etiology of hemodialysis catheter related blood stream infections at a tertiary care hospital in Mumbai: A 5 year review. Indian J Nephrol. 2020;30(2):132-3. 